\title{
Pengembangan Pengrajin Tikar di Gondangrejo Kabupaten Karanganyar
}

\author{
Isna Putri Rahmawati ${ }^{1}$, Doddy Setiawan ${ }^{2}$, Evi Gantyowati ${ }^{3}$, Aris Eddy Sarwono ${ }^{4}$ \\ 1,2,3 Program Studi Akuntansi, Fakultas Ekonomi dan Bisnis, Universitas Sebelas Maret, ${ }^{4}$ Program \\ Studi Akuntansi, Fakultas Ekonomi, Universitas Slamet Riyadi \\ isnaputrirahmawati@gmail.com
}

\begin{abstract}
ABSTRAK
Kegiatan pengabdian ini dilaksanakan di Desa Ngaglik dan Selokaton Gondangrejo, Karanganyar Jawa Tengah. Daerah tersebut memiliki potensi dalam menghasilkan tikar dan olahannya yang dikerjakan secara semi tradisional. Penduduk di sekitar wilayah tersebut mata pencaharian sebagian besar sebagai penentun tikar dan buruh tenun tikar. Desa tersebut mempunyai potensi dalam pengembangan ketrampilan pengrajin tikar. Masalah utama yang ada pada para pengrajin diantaranya masalah manajemen pengelolaannya (aspek akuntansi dan manajemen keuangan), proses produksi yang kurang optimal dan belum melakukan efisiensi dan proses produksi yang dilakukan serta penanganan sumber daya manusia. Kegiatan pengabdian ini dilaksanakan dengan menggunakan beberapa pendekatan, antara lain melalukan kegiatan pelatihan bidang manajemen dan ketrampilan, peragaan dan pemanfaatan alat yang akan diterapkan dan pelatihan SDM akan produk-produk yang dihasilkan. Pengabdian ini menambah 3 ATBM untuk proses produksi dan memenuhi pesanan dan penambahan benang untuk variasi motif. Selain itu juga terdapat pendampingan pembukuan, manajemen keuangan dan penguatan SDM.
\end{abstract}

Kata Kunci : Tikar, produktivitas, pengrajin, produksi

\section{ABSTRACT}

The community service activities were carried out in Ngaglik and Selokaton, Gondangrejo, Karanganyar, Central Java. The area has potential to produce mats and processed in a semitraditional way. Residents around the area are mostly livelihoods as mat makers and mat weaving workers. The village has the potential in developing mat craftsman skills. The main problems that exist in the SME include management issues (accounting and financial management aspects), the inefficiency production process, and human resources. The community service activities are carried out using a number of approaches, including through training in management and skills, demonstration and use of tools to be applied and training of human resources for the products produced. This activities adds 3 ATBM to supprt the production process and meet orders and adds yarn for a variety of motifs. In addition there is also assistance in bookkeeping, financial management and human resource strengthening.

Keywords: Mats, productivity, craftsmen, production

\section{PENDAHULUAN}

Usaha Mikro, Kecil, dan Menengah (UMKM) memiliki peran terhadap perkembangan perekonomian suatu negara. Kemampuan UMKM untuk dapat bertahan pada saat masa krisis adalah bukti bahwa UMKM cukup tangguh (Ling, 2013). Hal ini dikarenakan Pertama umumnya 
JAMALI - Volume. 01, Issue. 02, September 2019

UMKM menghasilkan barang konsumsi dan jasa yang dekat dengan kebutuhan masyarakat. Pendapatan masyarakat yang menurun ketika terjadi krisi tidak berpengaruh banyak terhadap permintaan barang dan jasa yang dihasilkan UMKM. Hal tersebut berbeda dengan kondisi usaha pada skala besar yang justru tumbang jika terjadi krisis. Yang kedua, dalam proses produksinya, UMKM menggunakan bahan baku dan tenaga kerja yang berasal dari sekitarnya (local). Kemudian yang terakhir yaitu, UMKM menggunakan modal sendiri dalam melakukan usaha. Artinya tidak menggunakan pinjaman dari perbankan (Meryana, 2012).

Kecamatan Gondangrejo, Kabupaten Karanganyar terbagi dalam 13 wilayah desa, dengan jumlah penduduk sebesar 69.897 jiwa. Berdasarkan data pada website kabupaten Karanganayar, Kecamatan Gondangrejo direncanakan menjadi Pusat Perdagangan dan Industri. Hal ini dikarenakan terdapat beberapa pabrik besar yang berlokasi di kecamatan ini. Oleh karena itu, sebagian besar penduduk usia produktif di kecamatan ini bekerja sebagai karyawan pabrik. Ada beberapa UKM yang menjadi ciri khas dari kecamatan ini. UKM tersebut memproduksi tikar.

UKM yang telah bekerja sama untuk melaksanakan program pengabdian adalah UKM Joko Sutrisno yang beralamatkan di Desa Ngaglik RT 5/8 Selokaton, Gondangrejo, Karanganyar Jawa Tengah dan UKM Suwondo yang beralamatkan di Pancuran RT1/9, Gondangrejo, Karanganyar. Desa tersebut terletak di perbatasan dengan Kabupaten Sukoharjo Sragen dan Kabupaten Boyolali memiliki potensi sejak puluhan tahun dalam menghasilkan tikar dan olahannya dikerjakan secara tradisional.

UKM Joko Sutrisno sebagai pengrajin Tikar yang sudah berdiri lebih dari 6 tahun di Desa Ngaglik, Selokaton, Gondangrejo Karanganyar. Sedangkan UKM Suwondo adalah UKM yang menjalankan usaha tikarnya lebih dari 5 tahun. UKM tersebut dalam menjalankan usahanya dilakukan dengan melibatkan para warga disekitar lokasi sebagai dan untuk menambah pendapatan keluarga masyarakat sekitarnya.

Kegiatan kerajinan tikar di Gondangrejo tersebut tergolong sangat prospektif. Kebutuhan bahan baku secara umum selama ini mudah untuk didapatkan walaupun perolehannya berasal dari Surabaya. Masalah yang berkaitan dengan bahan baku tertelak pada jumlah stok bahan baku yang tidak besar, mengingat UKM ini tergolong sebagai UKM yang sangat kecil, selain itu perolehan warna dasar bahan baku tergantung pada bahan baku yang diterima dari distributor (bahan baku berupa sisa benang dari pabrik karpet) Kondisi lingkungan kerja (ruang kerja) pada UKM Joko Sutrisno dan UKM Suwondo belum menggambarkan kondisi ruang kerja yang baik, sehingga perlu perbaikan kondisi ruang kerja sehingga kegiatan dalam proses pembuatan tikar dapat dilakukan lebih nyaman. Peralatan yang digunakan untuk melakukan proses pembuatan tikar pada UKM Joko Sutrisno terdiri dari alat tenun untuk tikar dan alat pemutar benang (Krir). Kondisi peralatan yang ada cukup memadahi, hanya jumlah peralatan yang masih minimal, mengingat selama ini kedua 
UKM belum mampu memenuhi pesanan dari pembeli. Kondisi peralatan yang ada pada kedua UKM dapat digambarkan pada gambar berikut:

Kondisi pengelolaan manajemen, keuangan dan administrasi masih menggunakan pola manajemen dengan pembukuan yang bersifat sangat sederhana, demikian pula dalam mencatat hasil produksi dan perencanaan produksi bahkan dalam hubungannya dengan pengendalian mutu produksi yang dilakukan belum menggambarkan pengelolaan yang efektif. Dalam hubungannya dengan masalah pemasaran produk-produknya, kedua UKM hanya menerima pesanan dari pembeli. Kedua UKM tersebut masih perlu dibina karena kedua UKM tersebut mempunyai potensi produktivitas yang bagus, yakni memiliki pangsa pasar regional dan dan pangsa pasar secara Nasional. Sistem pemasaran untuk kedua Kelompok UKM tersebut ada kesamaan satu sama lain yaitu model pemasaran yang dilakukan kurang proaktif dan hanya menerima pesanan dari pembeli dengan harga yang kurang kompetitif. Ditinjau dari kondisi sumber daya manusia (SDM) untuk UKM Joko Sutrisno hampir sebagian besar SDM utamanya karyawan yang ada di bagian produksi dimiliki lulusan pendidikan tingkat SMP. Sedangkan UKM Suwondo secara umum memiliki spesifikasi SDM dengan lulusan SLTP dan SLTA.

Fasilitas yang dimiliki oleh kedua UKM tersebut secara umum masih sederhana diantaranya ruang untuk proses produksi belum tertata secara maksimal termasuk tempat penyimpanan bahan dan hasil produksi (gudang) masih belum tertata dengan baik. Sedangkan untuk peralatan yang digunakan dalam proses produksinya sudah mencukupi kondisinya hanya jumlahnya masih sangat terbatas, sehingga tingkat produktivitas yang dilakukan tidak dapat dilakukan secara maksimal.

Maka dari itu, kegiatan pengabdian ini akan dilakukan dengan melihat tiga aspek utama yaitu Proses produksi, manajemen dan administrasi, dan pemasaran. Kegiatan ini ditujukan agar UKM mitra memiliki tambahan alat untuk mempermudah produksi. Selain itu UKM menjalankan usahanya dengan sederhana dan tradisional. Maka dari itu, Kegiatan pengabdian masyarakat ini dilaksanakan dengan pengadaan alat bantu untuk proses serta melakukan pendampingan dan pelatihan untuk tata kelola pelaksanaan usaha agar UKM Mitra dapat lebih kreatif, inovatif dan lebih berkembang.

\section{METODE}

Mengacu pada permasalahan pada UKM mitra, maka diperlukan metode pendekatan guna mendukung realisasi program pengabdian yaitu dengan metode penerapan yang dilakukan dengan tahapan sebagai berikut: 


\begin{tabular}{|c|c|c|c|}
\hline $\begin{array}{c}\text { Permasalahan } \\
\text { UKM }\end{array}$ & $\begin{array}{l}\text { Luaran } \\
\text { UKM I }\end{array}$ & $\begin{array}{l}\text { Luaran } \\
\text { UKM II }\end{array}$ & \\
\hline $\begin{array}{l}\text { Produksi dan } \\
\text { Proses } \\
\text { produksi }\end{array}$ & $\begin{array}{l}\text { 1) Menambah } 2 \text { (dua) } \\
\text { ATBM untuk } \\
\text { peningkatan produksi } \\
\text { yang optimal } \\
\text { 2) Menghasilkan produk } \\
\text { tikar yang memiliki } \\
\text { motif yang berbeda } \\
\text { yang berasal dari } \\
\text { pewarnaan bahan dasar } \\
\text { benang melalui } \\
\text { pewarnaan bahan baku } \\
\text { benang. }\end{array}$ & $\begin{array}{l}\text { 1) Menambah 1 (satu) } \\
\text { ATBM untuk } \\
\text { peningkatan produksi } \\
\text { yang optimal } \\
\text { 2) Menghasilkan produk } \\
\text { tikar yang memiliki } \\
\text { motif yang berbeda } \\
\text { yang berasal dari } \\
\text { pewarnaan bahan dasar } \\
\text { benang melalui } \\
\text { pewarnaan bahan baku } \\
\text { benang. }\end{array}$ & $\begin{array}{l}\text { 1) Merancang tambahan } \\
\text { mesin atbm yang } \\
\text { disesuaikan dengan } \\
\text { kebutuhan UKM } \\
\text { 2) Menjelaskan model } \\
\text { pewarnaan pada bahan } \\
\text { baku benang }\end{array}$ \\
\hline $\begin{array}{l}\text { Manajemen } \\
\text { dan } \\
\text { administrasi }\end{array}$ & $\begin{array}{l}\text { 1) Pembukuan akuntansi } \\
\text { sederhana dan } \\
\text { perpajakan } \\
\text { 2) Pelatihan manajemen } \\
\text { dan kewirausahaan }\end{array}$ & $\begin{array}{l}\text { 1) Pembukuan akuntansi } \\
\text { sederhana } \\
\text { 2) Pelatihan manajemen } \\
\text { dan } \\
\text { kewirausahaan }\end{array}$ & $\begin{array}{l}\text { 1) Memberikan pelatihan } \\
\text { mengenai masalah } \\
\text { akuntansi sederhana } \\
\text { untuk UKM, } \\
\text { kewirausahaan } \\
\text { 2) Memperagakan bentuk } \\
\text { pelatihan yang diberikan } \\
\text { utamannya } \\
\text { untukpelatihan } \\
\text { pembukuan sederhana } \\
\text { untuk UKM }\end{array}$ \\
\hline$S D M$ & $\begin{array}{l}\text { Peningkatan Skill SDM } \\
\text { melalui: Pelatihan } \\
\text { bidang SDM, leadership } \\
\text { dan etos kerja }\end{array}$ & $\begin{array}{l}\text { Peningkatan Skill SDM } \\
\text { melalui: Pelatihan } \\
\text { bidang SDM, leadership } \\
\text { dan etos kerja. }\end{array}$ & $\begin{array}{l}\text { Melakukan pelatihan } \\
\text { dengan para UKM dan } \\
\text { pengembangan SDM, } \\
\text { masalah kepemimpinan } \\
\text { dan semangat kerja. }\end{array}$ \\
\hline
\end{tabular}

\section{HASIL DAN PEMBAHASAN}

Kegiatan pengabdian ini dilakukan dengan melihat beberapa aspek pada UKM Mitra, yaitu masalah proses produksi, manajemen dan administrasi, serta sumber daya manusia. Pada tahap 
laporan kemajuan ini, kegiatan yang sudah dilakukan adalah pada bagian produksi dan manajemen serta administrasi UKM. Beberapa tahapan yang telah dilakukan meliputi:

\section{Produksi dan Proses produksi}

Proses produksi merupakan proses yang mengubah bahan baku menjadi produk jadi dengan menggunakan tenaga kerja dan sumber daya overhead lainnya (Vanderbeck, 2010). Pada 2 UKM Mitra ini, proses tenun tikar dilakukan secara manual oleh tangan manusia. Pekerja adalah para perempuan di sekitar lokasi UKM. Kedua UKM ini juga sedang mengembangkan alat ATBM yang terotomatisasi. Namun, hal ini membutuhkan dana dan keahlian perakit alat tersebut. Sehingga, sudah hampir setahun proses pembuatan mesin yang otomatis masih dalam proses. Kendala utama pada UKM I adalah terbatasnya alat ATBM manual yang dibawa oleh para karyawan ke rumah, sehingga belum maksimalnya produksi. Hal ini dikarenakan tidak semua karyawan selalu aktif menyetor pekerjaan tikarnya ke UKM Pak Joko. Terdapat beberapa alasan yaitu, misal musim tanam di sawah maupun jika ada tetangga yang sedang punya hajatan maka para karyawan tersebut ijin tidak menenun tikar. Untuk teteap menjaga produskinya dan memenuhi pesanan maka pada UKM I (UKM Pak Joko) ATBM untuk peningkatan produksi yang optimal.

Untuk UKM II (Pak Suwondo), permasalahan mengenai alat dan karyawan juga hampir sama dengan UKM I. Namun, UKM II sudah memiliki lebih banyak karyawan yang tersebar ke beberapa RT. Pesanan di UKM II hampir 2x lipat dari UKM I. Selama ini Pak Suwondo belum bisa memenuhi semua pesanan yang masuk karena kurangnya mesin ATBM yang disebar ke beberapa karyawan. Selain itu juga, UKM ini memberikan benang baru untuk dapat memberi motif yang baik bagi UKM Tikar. Selama ini UKM Tikar menggunakan benang sisa produksi dari garmen, sehingga motifnya kurang bagus karena benang dengan warna yang sama cepat habis.

\section{Manajemen dan administrasi}

Kedua UKM Mitra kegiatan pengabdian masyarakat (UKM Pak Suwondo dan Pak Joko) pada awalnya hanya melakukan pencatatn yang sangat sederhana. UKM melakukan pencatatan hanya pada pesanan yang diterima. UKM tidak mencatat keseluruhan transaksi yang terkait dengan kegiatan usahanya. Selain itu pemilik hanya mengingat-ingat pencatan kegiatan usahanya, masih tercampurnya beberapa pengeluaran lain-lain misalnya biaya listrik yang masih bercampur dengan pengeluaran rumah tangga.

Pendampingan yang tim pengabdi lakukan adalah dengan memberikann pemahaman mengenai manajemen keuangan dan pembukuan sederhana.Yang pertama, pendampingan mengenai manajemen keuangan adalah bahwa UKM harus memisahkan pengeluaran antara pengeluaran pribadi (keluarga) dengan pengeluatan untuk kepentingan usaha. Hal ini ditujukan untuk 
mengetahui berapa sebenarnya keuntungan dari usaha. Keuntungan tersebut dapat digunakan untuk evaluasi kegiatan usahanya. Kemudian yang kedua yaitu pendampingan pembukuan sederhana. Menurut Rianti dan Swadarma (2012), pembukuan merupakan suatu aktivitas mencatat segala macam transaksi keuangan. Transaksi keuangan ini bisa mencakup beberapa hal, seperti pembelian, penjualan, pendapatan, dna pengeluaran perseorangan maupun kelompok dalam organisasi. Maka dari itu, tim pengabdian masyarakat ini memberikan form usulan untuk memudahkan dalam melakukan pembukuan sederhada. Form tersebut berisi buku besar untuk kas, persediaan (baik bahan baku, setengah jadi, dan produk jadi), utang, piutang serta penjualan.

Materi pendampingan yang kedua adalah mengenai penentuan harga pokok produksi tikar. Biaya produksi terdiri dari biaya bahan baku, biaya tenaga kerja langsung, dan biaya overhead pabrik. Biaya overhead pabrik merupakan biaya langsung pabrik yang harus dialokasikan ke unit produk. Berdasarkan diskusi, UKM sudah melakukan pembebanan harga pokok produksi dengan perhitungan yang tepat. Akan tetapi,mereka hanya melakukan perhitungan menggunakan selisih kenaikan harga dari penentuan HPP pada saat awal mulai produksi. Tim pengabdian memberikan saran agar UKM dapat melakukan pencatatan setiap saat agar mendapatkan harga pokok yang sesuai.

Tim pengabdian juga memperkenalkan aplikasi pencatatan akuntansi dengan menggunakan aplikasi yaitu La Mikro dan SI Apik. Akuntansi yang berbasis kas ini dilakukan dengan membuat catatan atas kas masuk dan kas keluar. Selain itu kami juga memberikan alternatif pembukuan kas dengan menggunakan aplikasi pada android yaitu Akun Biz. Tim pengabdi juga menambahkan adanya aplikasi yang dari Kementrian Koperasi dan UKM yaitu La Mikro yang sudah sesuai dengan Standar Akuntansi Keuangan EMKM. Kedua, Mengadakan Pelatihan manajemen dan kewirausahaan. Dalam pelatihan ini,diajarkan mengenai bagaimana pengelolaan usaha dan motivasi berwirausaha yang selallu dijaga. Hal ini dikarenakan UKM binaan dalam kegiatan pengabdian ini hanya mengandalkan pesanan dalam menjalankan usahanya. Dalam pelatihan ini diberikan bekal bahwa dalam berwira usaha, harus selalu melakukan upaya dalam memanfaatkan aset maupun tenaga kerja yang dimilikinya. Hal ini bertujuan untuk memaksimalkan kapasitas produksi. Maka dari itu, tidak ada aset yang menganggur. Sehingga dapat digunakan untuk menghasilkan pendapatan.

\section{Sumber Daya Manusia}

Pengingkatan di skill Sumber daya manusia dalam usaha ini yang diekspektasikan adalah melalui pelatihan di bidang SDM, leadership dan etos kerja. Selama ini etos kerja dari para karyawan UKM sudah baik, hanya belum ada komitmen yang tepat dalam melaksanakan pesanan dari pelanggan. Karyawan belum merasa terpacu untuk memenuhi target. 


\section{SIMPULAN}

Pada kegiatan pengabdian ini diharapkan dapat memberikan solusi atas permasalahan yang terjadi di UKM Tikar. Kegiatan pengabdian ini terdiri dari solusi atas permasalahan pada kegiatan produksi, manajemen dan administrasi, serta manajemen SDM.. Hal ini dilakukan dengan tujuan agar UKM tersebut dapat lebih memperkuat kemampuan secara internal (proses produksi, manajemen dan administrasi) serta secara eksternal yaitu melalui kegiatan pemasaran. Pelaksanaan kegiatan yang sudah dilakukan oleh Tim Pengabdi sangat membutuhkan partisiasi dan keinginan kuat dari para UKM untuk mau melakukan perubahan. Hal ini bertujuan agar kegiatan penampingan yang dilakukan dapat berjalan secara mandiri.

\section{UCAPAN TERIMA KASIH}

Tim Pengabdian Masyarakat dalam kegiatan ini mengucapkan terima kasih kepada:

a. LPPM Universitas Sebelas Maret yang telah memfasilitasi pendanaan dari kegiatan pengabdian masyarakat ini.

b. Mitra UKM Kegiatan Pengabdian Masyarakat di Kec.Gondangrejo, Kab. Karanganyar.

\section{Daftar Pustaka}

Jafar Hafsah. 2004. Upaya Pengembangan Usaha Kecil Dan Menengah (UKM). Infokop Nomor 25 Tahun XX.

Kenneth N. Wexley. 1991. Developing and Training Human Resources in Organizations.

Kuncoro, M. 2002. Analisis Spasial dan Regional: Studi Aglomerasi dan Kluster Industri Indonesia. Yogyakarta: UPP-AMP YKPN.

Meryana, Ester. 2012. "Tiga Hal yang Buat UMKM Tahan Krisis", https:/ekonomi.kompas.com/read/2012/03/28/11093274/Tiga.Hal.yang.Buat.UMK M.Tahan.Krisis.

Panduan Penelitian dan Pengabdian kepada masyarakat Lembaga Penelitian dan Pengabdian Masyarakat (LPPM UNS) Edisi XII tahun 2019.

Rianti, A A dan D. Swadana. 2012. Pembukuan Sederhana Usaha Dagang dan Jasa (Untuk Perusahaan Kecil dan Menengah). Jakarta: Laskar Aksara.

Vanderbeck, Edward J. 2010. Principles of Cost Accounting, 15th edition, South Western, Cengage Learning 